Western University

Scholarship@Western

Obstetrics \& Gynaecology Publications

Obstetrics \& Gynaecology Department

$12-1-2000$

\title{
mRNAs encoding aquaporins are present during murine preimplantation development.
}

H Offenberg

L C Barcroft

A Caveney

D Viuff

P D Thomsen

See next page for additional authors

Follow this and additional works at: https://ir.lib.uwo.ca/obsgynpub

Part of the Obstetrics and Gynecology Commons

Citation of this paper:

Offenberg, H; Barcroft, L C; Caveney, A; Viuff, D; Thomsen, P D; and Watson, A J, "mRNAs encoding aquaporins are present during murine preimplantation development." (2000). Obstetrics \& Gynaecology Publications. 62.

https://ir.lib.uwo.ca/obsgynpub/62 
Authors

H Offenberg, L C Barcroft, A Caveney, D Viuff, P D Thomsen, and A J Watson 
Accepted to Molecular Reproduction and Development

mRNAs encoding Aquaporins are present during Murine Preimplantation Development

Hanne Offenberg ${ }^{1,2,3}$ Lisa C. Barcroft ${ }^{3}$, Anita Caveney ${ }^{3}$, Dorthe Viuff ${ }^{1,2}$, Preben D. Thomsen ${ }^{1,2}$ \& Andrew J. Watson ${ }^{3 *}$

${ }^{1}$ Department of Clinical Studies, Reproduction, ${ }^{2}$ Department of Anatomy and Physiology, Royal Veterinary and Agricultural University, DK-1870 Frederiksberg C, Denmark; ${ }^{3}$ Departments of Obstetrics and Gynaecology \& Physiology, The University of Western Ontario, London, Ontario, Canada, N6A 5C1

Running Title: Aquaporins during Murine Preimplantation Development

Keywords: oocyte, blastocyst, trophectoderm, water transport, cell polarity,

*Correspondence to: Dr. A.J. Watson, Departments of Obstetrics and Gynaecology \& Physiology, Rm 238 Medical Sciences Bldg, The University of Western Ontario, London, Ontario, Canada, N6A 5C1; ph (519) 661-3467; fax (519) 661-3827; awatson@physiology.uwo.ca 


\begin{abstract}
The present study was conducted to investigate the mechanisms underlying fluid movement across the trophectoderm during blastocyst formation by determining whether aquaporins (AQPs) are expressed during early mammalian development. AQPs belong to a family of major intrinsic membrane proteins and function as molecular water channels that allow water to flow rapidly across plasma membranes in the direction of osmotic gradients. Ten different AQPs have been identified to date. Murine preimplantation stage embryos were flushed from the oviducts and uteri of superovulated CD1 mice. Reverse-transcription-polymerase chain reaction (RTPCR) methods employing primer sets designed to amplify conserved sequences of AQPs (1-9) were applied to murine embryo cDNA samples. PCR reactions were conducted for up to 40 cycles consisting of denaturation of DNA hybrids at $95{ }^{\circ} \mathrm{C}$, primer annealing at $52-60{ }^{\circ} \mathrm{C}$ and extension at $72{ }^{\circ} \mathrm{C}$. PCR products were separated on $2 \%$ agarose gels and were stained with ethidium bromide. AQP PCR product identity was confirmed by sequence analysis. mRNAs encoding AQPs $1,3,5,6,7$, and 9 were detected in murine embryos from the one cell stage up to the blastocyst stage. AQP 8 mRNAs were not detected in early cleavage stages but were present in morula and blastocyst stage embryos. The results were confirmed in experimental replicates applied to separate embryo pools of each embryo stage. These results demonstrate that transcripts encoding seven AQP gene products are detectable during murine preimplantation development. These findings predict that AQPs may function as conduits for trophectoderm fluid transport during blastocyst formation.
\end{abstract}




\section{INTRODUCTION}

The preimplantation period of mammalian development is characterized by a series of cell divisions leading to the formation of a blastocyst. The blastocyst is composed of the outer epithelial trophectoderm, a fluid-filled cavity, and a small group of cells, the inner cell mass (ICM) which are the progenitors of the embryo proper ( McLaren 1982; Wiley 1987; Biggers et al., 1988; Watson 1992). Trophectoderm differentiation begins during compaction (onset of cell to cell adhesion) and is completed during cavitation (blastocyst formation). These events are dependent upon the $\mathrm{Ca}^{++}$-mediated cell to cell adhesion provided by E-cadherin, the establishment of a tight junctional permeability seal and the polarized distribution of the $\mathrm{Na} / \mathrm{K}$ ATPase (Vestweber et al., 1987; Fleming et al., 1987; Watson et al., 1990b).

The trophectoderm is the first ion-transporting epithelium formed during development and provides an important model allowing the investigation of functions and characteristics of a transporting epithelium in vitro. Blastocyst formation is essential for implantation and subsequent development. Failure to reach this developmental stage and implant is a principal cause of early pregnancy loss (McLaren 1982; Bolton 1992; Edwards 1997).

Transporting epithelia are characterized by the rapid passage of water (Zeuthen 1995; Wintour 1997; Spring 1998; Zeidel 1998). Water permeability is a universal property of cell membranes, but how this permeability is mediated at the molecular level is still poorly understood. Water can cross the plasma membrane by simple diffusion driven by either concentration gradients of ions and solutes which generate an osmotic force, or by physical pressure, generating a hydrostatic force (Dainty 1965; Zeuthen 1995; Spring 1998). The diffusional permeability $\left(P_{d}\right)$ of cell membranes varies but is usually small ie $<1$ m min $^{-1}$ atm $^{-1}$ 
(Dainty 1965; Zeuthen 1995; Spring 1998). Although this value is low, it is sufficient for most cell types to regulate their volumes. Water flow in some cell types such as red blood cells is, however, much greater than that produced by simple diffusion alone (Paganelli \& Solomon 1957). This has resulted in the hypothesis that cell membranes possess pores that facilitate water flow (Zeuthen 1995; Wintour 1997; Spring 1998; Zeidel 1998). Evidence supporting the presence of "water channels" has come from biophysical studies of red blood cells, kidney collecting ducts and toad bladder epithelial cells (Harris \& Zeidal 1993; Mulders et al., 1996; Lee et al., 1997; Deen \& van Os 1998; Verkman, 1999).

Aquaporins (AQPs) belong to a family of major intrinsic membrane (MIP) proteins. AQPs function as molecular water channels that allow water to flow rapidly across plasma membranes in the direction of osmotic gradients. To date 10 different AQPs have been identified in mammals, with more likely to come (Harris \& Zeidal 1993; Mulders et al., 1996; Wintour 1997; Agre 1997; Lee et al., 1997; Deen \& van Os 1998). The expression of AQP gene products during the first week of mammalian development has not been fully investigated. Furthermore the mechanisms controlling water movement across the trophectoderm during blastocyst formation are unexplored. We hypothesize that AQP water channels are present in the trophectoderm cells of the preimplantation embryo and that they function as conduits for the trans-trophectodermal fluid movements associated with blastocyst formation. The purpose of this study was to determine the full complement of mRNAs encoding AQPs during preimplantation mouse embryos. We have determined that up to seven members of this gene family are present during the first week of mammalian development. 


\section{MATERIALS AND METHODS}

\section{Superovulation and mouse embryo collection:}

Female CD-1 mice (Charles River, Canada), 15-18 grams, were injected with 5 IU PMSG (Sigma, St Louis, MO) followed by 5 IU hCG (Sigma) 48 hours later and mated with CB6F1/J males. Successful mating was determined the next morning (day 1 ) by detection of a vaginal plug. Time post-hCG was used to measure the developmental age of the embryos which were collected at $18 \mathrm{hr}$; unfertilized oocytes; 48 hr, 2-cells; 60 hr, 4-cells; $65-68$ hr, 8-cells; 80-85 hr, morulae and $90 \mathrm{hr}$, blastocysts. Days 1 to 3 embryos (zygotes through 8-cell compacted) were flushed from the reproductive tract using flushing medium I while day 4 embryos were flushed with flushing medium II (Spindle, 1980). Flushing medium I consists of calcium lactate (1.71 mM), sodium pyruvate $(0.25 \mathrm{mM})$ and bovine serum albumin $(3 \mathrm{mg} / \mathrm{ml})$ added to $10 \mathrm{X}$ Leibovitz-modified Hank's balanced salt solution (HBSS) and diluted with water to 1 X (Spindle, 1980). Flushing medium II consisted of $\mathrm{CaCl}_{2}(1.8 \mathrm{mM})$, amino acids (L-arginine, L-cystine, L-histidine, L-isoleucine, L-leucine, L-lysine, L-methionine, L-phenylalanine, L-threonine, L-tryptophan, I-tyrosine, L-valine, and Lglutamine at $0.1,0.5,1.03,0.2,1.0,2.0,0.25,0.5,2.0,0.1,0.1,1.0$, and $2.0 \mathrm{mM}$ respectively) and $1 \mathrm{X}$ BME vitamins to 10X Leibovitz -modified HBSS diluted with water to $1 \mathrm{X}$ (Spindle, 1980). Embryos were washed 4-5 times in flushing medium and quick-frozen in a small amount of medium using liquid nitrogen, in batches of 30-50 embryos. They were stored at $-70{ }^{\circ} \mathrm{C}$ until RNA extraction

\section{RNA extraction:}


Total embryo RNA was extracted from pools of 30-50 preimplantation stage embryos using phenol chloroform and ethanol precipitation as previously described (Watson et al., 1992). Embryos were placed into $100 \mu$ l of extraction buffer (0.2 M NaCl, 1 mM EDTA, 25 mM TRIS HCl, $\mathrm{pH}$ 7.4) with $12 \mu \mathrm{g}$ carrier $E$. Coli ribosomal RNA and were vortexed with equal volumes of phenol and chloroform:isoamyl alcohol (24:1), centrifuged, re-extracted with $100 \mu$ of chloroform:isoamyl alcohol, and then precipitated with $95 \%$ ethanol at $-20^{\circ} \mathrm{C}$ overnight. The samples were then centrifuged, washed with $70 \%$ ethanol $\left(-20^{\circ} \mathrm{C}\right)$, re-centrifuged, and air-dried before being re-dissolved in $10 \mu \mathrm{l}$ sterile water. Mouse kidney, liver and lung RNA were extracted by the same method and were quantified via spectrophotometry. Aliquots of $1 \mu \mathrm{g}$ tissue total RNA was used for reverse transcriptions.

\section{Reverse Transcription and Polymerase Chain Reaction (RT-PCR):}

Total RNA was reverse-transcribed (RT) using oligo (dT) priming and Superscript ${ }^{\text {tm }}$ Rnase H-Reverse Transcriptase (Gibco BRL, Burlington, ON, Canada; Watson et al., 1992b, 1994; Harvey

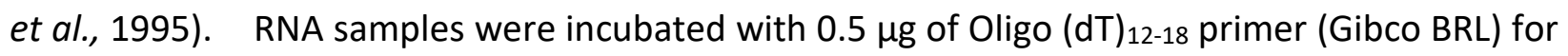
10 min at $70^{\circ} \mathrm{C}$. Following cooling on ice, RNA was incubated in $1^{\text {st }}$ Strand Buffer (Gibco BRL; containing $50 \mathrm{mM}$ Tris- $\mathrm{HCl}$ [pH 8.3], $75 \mathrm{mM} \mathrm{KCl,} 3 \mathrm{mM} \mathrm{MgCl}$, $10 \mathrm{mM} \mathrm{DTT}, 0.5 \mathrm{mM}$ dNTPs) and 200 units of Superscript Reverse Transcriptase (Gibco BRL) for $1.5 \mathrm{~h}$ at $43^{\circ} \mathrm{C}$. The reaction was terminated by heating at $94^{\circ} \mathrm{C}$ for 5 min and flash cooling on ice. Polymerase chain reaction (PCR) was performed as previously described (Watson et al., 1992b, 1994; Betts et al., 1996). Aliquots of 2 embryo equivalents were amplified with 1 unit AmpliTaq Gold (Perkin Elmer, PE Applied Biosystems, Mississauga, ON) in a final volume of $50 \mu$ l containing 1 X PCR buffer II plus $1.5-2.5$ 
$\mathrm{mM} \mathrm{MgCl} 2,0.2 \mathrm{mM}$ of each dNTP and 1 ? $\mathrm{M}$ of each gene-specific primer. The reaction mixture was amplified in a DNA thermal cycler (Perkin Elmer GeneAmp PCR system 2400). The reaction was initiated at $95^{\circ} \mathrm{C}$ for 10 mins, followed by 40 cycles consisting of denaturation at $95^{\circ} \mathrm{C}$ for 1 min, re-annealing of primers to target sequences at $52-57^{\circ} \mathrm{C}$ for $30 \mathrm{sec}$ and primer extension at $72^{\circ} \mathrm{C}$ for $1 \mathrm{~min}$. The reaction was ended with a $10 \mathrm{~min}$ extension at $72^{\circ} \mathrm{C}$. PCR products were resolved on $2 \%$ agarose gels containing $0.5 \mu \mathrm{g} / \mathrm{ml}$ of ethidium bromide. PCR reactions for each AQP primer set were repeated on cDNA samples prepared from each embryo stage representing three distinct and complete developmental series.

\section{PCR Primers:}

Primer sequences for actin and AQPs 1-9 were designed from cDNA sequences retrieved from GENBANK and were synthesized by Gibco BRL,(see Table 1 for sequences). AQPs 3, 4, 5, 6, 7 and 9 were designed from rat sequences and AQP 1, 2 and 8 were designed from mouse sequences. The primer sets were designed to recognize conserved cross species sequence regions. For example primer sets encoding AQPs 1,2,3,4,5, and 7, share a $100 \%$ homology to both rat and mouse sequences. Murine sequences for AQPs 6 and 9 are not available as yet and only rat sequences are known. The AQP 8 primer set was designed from mouse AQP 8 sequences. The specificity of each primer set for recognizing its specific sequence was determined by running Genbank sequence homology searches and by sequence analysis of the PCR products. In each case the primers sets displayed an ability to recognize and amplify only their specific AQP family member. cDNA samples were tested for presence of genomic DNA contamination prior to use in gene-specific RT-PCR reactions by utilizing a set of primers designed to bracket an intron of the 
$\beta$-actin cDNA. In the absence of genomic DNA, this primer set produces a $243 \mathrm{bp}$ amplification product (Watson et al., 1992b, 1994; Harvey et al., 1995). All cDNA samples utilized in this study displayed the amplification of the appropriate sized $\beta$-actin cDNA PCR product. At no time did we detect the larger intron spanning product representing actin genomic DNA.

\section{Cloning and Sequencing of AQP RT-PCR Products:}

The murine AQP RT-PCR products were cloned into PGEM-T vector using the pGEM-T Vector System (Promega, Fisher Scientific, Nepean, ON; Natale et al., 2000). The ligated inserts were transformed into XL-1 Blue high efficiency competent cells and spread on separate LB agar plates containing $100 \mathrm{gg} / \mathrm{ml}$ ampicillin (Sigma -Aldrich Canada, Oakville, ON, Canada), 80 ?g/ml X-gal (Gibco BRL) and 0.5 mM IPTG (Gibco BRL). Single colonies were picked and inoculated for overnight culture at $37{ }^{\circ} \mathrm{C}$ with shaking at $250 \mathrm{rpm}$. Plasmid DNA was purified using the QIAprep Mini prep kit (QIAGEB Inc., Mississauga, On, Canada; Natale et al., 2000). Plasmid DNA was amplified by PCR using a reaction mix containing $1.25 \mathrm{U}$ of Taq DNA Polymerase (Gibco BRL) containing 1X Taq reaction buffer (20 mM Tris- $\mathrm{HCl}$, pH 8.4 and $50 \mathrm{mM} \mathrm{KCl}$ ), plus $2.5 \mathrm{mM} \mathrm{MgCl}$, $0.15 \mathrm{mM}$ dNTPs and $0.16 \mu \mathrm{M}$ of each sequence-specific primer (bracketing the plasmid insertion site) in a final $20 \mu$ volume. The mixture was overlaid with mineral oil and then amplified by PCR

for 45 cycles in a DNA thermal cycler (GeneAMP 2400, Perkin Elmer) with each cycle consisting of denaturation at $94^{\circ} \mathrm{C}$ for $30 \mathrm{sec}$, re-annealing of primers to target sequences at $50^{\circ} \mathrm{C}$ for 30 sec, and primer extension at $72^{\circ} \mathrm{C}$ for $30 \mathrm{sec}$ concluded with a final extension at $72^{\circ} \mathrm{C}$ for 5 min (Natale et al., 2000). PCR products were run on $2 \%$ agarose gels containing $0.5 \mu \mathrm{g} / \mathrm{ml}$ of ethidium bromide. The presence of a single expected size AQP amplicon verified that the expected product was cloned (Natale et al., 2000). Identity of products from each PCR reaction was verified by 
sequencing conducted at the Robarts Research Institute, University of Western Ontario, ON, Canada. 


\section{RESULTS}

\section{AQP Transcripts during Murine Preimplantation Development}

Figure 1 displays the typical pattern of expression observed for AQP mRNAs in samples derived from positive control tissue samples and pooled murine 1-cell embryos, 2-cell embryos, 4-cell embryos, 8-cell embryos, morulae, blastocysts and negative controls (-cDNA). The assays were repeated a minimum of three times with pools of embryos collected from replicate cultures. Each reverse-transcribed embryo cDNA sample was first tested with $\beta$-actin primers to ensure the absence of contaminating genomic DNA.

Transcripts encoding AQPs 1,3,5,6, 7, and 9 (indicated by amplicons having the predicted sizes of 462 bp, 398 bp, 260 bp, 304 bp, 269 bp and 278 bp respectively) were detected in 1-cell murine zygotes to blastocyst stages (Figure 1). In each case, the distribution of these transcripts throughout pre-attachment development is suggestive of these gene products being of both maternal (oogenetic) and embryonic origin. Transcripts encoding AQP 8 were undetectable in early cleavage stage embryos ( 1 cell to 8 cell stage) but were consistently detected in morula and blastocyst stages (Figure 1; 497 bp product). This pattern of expression is indicative of transcription from the embryonic genome. Although our assay was not a quantitative one the amplicon signals were consistently more intense for AQPs 3, 7 and 8 in morula and blastocyst stages (Figure 1) which is suggestive of a possible increase in mRNA accumulation for these AQPs just prior to blastocyst formation. We were unable to detect any transcripts encoding AQPs 2 and 4 in any preimplantation embryo stage (Figure 1). The expected size products for each AQP were 
detected in control murine tissues representing kidney for AQPs 1,2,3,4, and 6, liver for AQPs 7, 8, and 9 and lung for AQP 5 (Figure 1).

\section{Verification of AQP Amplicon Identity by Sequence Analysis}

To confirm the identity of AQP 1,3,5, 6,7, 8 and 9 embryonic amplicons and to contrast the nucleotide sequence identity of AQP 6 , and 9 mouse and rat sequences each murine embryonic AQP RT-PCR product was cloned and sequenced. The nucleotide sequences are displayed in Figure 2. Each sequence was directly compared to the corresponding published murine or rat cDNA sequence (rat sequences were used in cases where murine sequence were previously uncharacterized ie AQPs 6 and 9) by conducting an alignment analysis using the BCM search launcher (http://kiwi:bcm.tmc.edu.8088/search-launcher/launcher.html). Nonconserved nucleotides are highlighted for each amplicon (Figure 2). 


\section{DISCUSSION}

In this study, we report the presence of transcripts encoding AQPs 1,3,5,6,7,8 and 9 during the first week of mammalian development. The oligodeoxynucleotide primers were designed through use of mouse and rat cDNA sequences obtained from searching GenBank. Their ability to amplify specific murine embryonic cDNAs was verified in all cases by observing the expected size of the amplified DNA fragment in several replicates of murine early developmental embryo stages. In addition each murine embryonic amplicon was sequenced for verification of identity.

Simple transporting epithelia arise from the differentiation of non-polar cells into polarized cells by the expression of gene families involved in cell adhesion, cell junctions and ion transport. These epithelia perform the function of transporting ions, solutes, and fluids in a directional manner (Simmons 1992; Wilson 1997; Davies \& Garrod 1997; Murer \& Biber 1998).

The trophectoderm forms the outer layer of the blastocyst, the fluid-filled structure the embryo assumes just prior to implantation into the uterine wall (Biggers et al., 1988; Wiley et al., 1990; Watson, 1992). Blastocyst formation is essential for implantation and subsequent development (McLaren, 1982; Wiley et al., 1990; Bolton, 1992; Edwards 1997). The trophectoderm is the first ion transporting epithelium formed during development and provides an important model allowing the investigation of cell polarity during development (Wiley et al., 1990; Watson, 1992). Our studies have investigated cell adhesion molecules, tight-junction associated polypeptides (Watson et al., 1990b; Barcroft et al., 1998), Na/K-ATPase isoforms (Watson and Kidder, 1988; Watson et al., 1990a; Betts et al., 1997; 1998), and growth factors (Watson et al., 1992; Watson et al., 1994; Winger et al., 1997) during trophectoderm differentiation. The principal hypothesis we are testing predicts that blastocyst formation is 
mediated by a trans-trophectoderm ion gradient(s) established, in part, by $\mathrm{Na} / \mathrm{K}$-ATPase, which drives the movement of water through aquaporins (AQPs) across the epithelium into the extracellular space of the blastocyst cavity.

Blastocyst expansion is restricted by ouabain (potent inhibitor of Na/K-ATPase (Dizio and Tasca 1977; Horisberger, 1995; Baltz et al., 1997) and blastocyst re-expansion following cytochalasin-induced collapse is completely blocked by ouabain (Dizio and Tasca, 1977; Baltz et al., 1997; Betts et al., 1997). Our studies determined that transcripts encoding the alpha 1 isoform accumulate from the murine 2-cell to early blastocyst stage (Watson et al., 1990a). alpha 1-subunit transcripts in this species are present in 2-, 4-, and 8-cell embryos but increase greatly in abundance by the morula and blastocyst stages (Watson et al., 1990a). By applying RT-PCR methods we have observed that mRNAs encoding the alpha 3 , alpha 2, alpha 3 isoforms are also expressed throughout murine preimplantation development (MacPhee et al., 2000). Thus at least four $\mathrm{Na}$ /K-ATPase isoform genes are expressed in the murine blastocyst (MacPhee et al., 2000). Blastocyst formation is accompanied by an increase in the level of ß1-subunit mRNA (Watson et al., 1990a), ß1- subunit protein (Gardiner et al., 1990), and enzyme activity (Vorbrodt et al., 1977; Betts et al., 1998). Polypeptides encoding the alpha 1 isoform maintain a polarized distribution confined to the basolateral membrane domains of the murine trophectoderm (Watson et al., 1988; Betts et al., 1997). The Na/K-ATPase gene family is an important facilitator of blastocyst formation, however, the precise contribution of each isoform of the $\mathrm{Na} / \mathrm{K}-\mathrm{ATPase}$ plays in establishing a trans-trophectoderm ionic gradient is unknown but is under investigation.

The mechanisms that facilitate the movement of water across the trophectoderm down 
the trans-trophectoderm ionic gradient are unexplored. The processes that regulate the uptake and release of water by living cells are fundamental to cell viability. Water can diffuse through lipid bilayers, so all cell membranes display some level of permeability to water (for review see Zeuthen, 1995; Wintour, 1997; Verkman 1999, Borgnia et al., 1999). It has been thought that simple diffusion was the primary if not exclusive mechanism for mediating water movement through biological membranes and that water channels were not necessary (Borgnia et al., 1999). Extensive research conducted largely over the past ten years has indicated that plasma membranes display a varied permeability to water movement and that in cases of rapid and large volume water movement that specific water transport molecules must exist (for review see Zeuthen, 1995; Wintour, 1997, Verkman, 1999, Borgnia et al., 1999). These types of studies have resulted in the characterization of 10 molecular water channels or Aquaporins. AQP 0/MIP28 was isolated from lens epithelium. Absence of normal AQP 0 protein is linked to cataract formation in mutant mice (Shiels \& Griffin 1993). AQP 1/channel forming integral membrane protein (CHIP)28 is the most ubiquitous of the AQP family and is expressed in a number of organs and tissues (Echvarria et al., 1994; Yang \& Verkman 1997; Heymann et al., 1998; Yang et al., 1999). AQP 1 is the major water channel in red blood cells and in the brain it is only found in the choroid plexus (Echvarria et al., 1994; Yang \& Verkman 1997; Heymann et al., 1998; Yang et al., 1999). AQP 2 is the vasopressin responsive water channel found in kidney collecting ducts (Fushimi et al., 1993; Katsura et al., 1996; Sasaki et al., 1998). This water channel is stored in cytoplasmic vesicles that fuse with the apical membrane following exposure to vasopressin (Katsura et al., 1996). Loss of function mutations in this gene result in nephrogenic diabetes insipidus (van Lieburg et al., 1994). AQP 3 permits the passage of water, glycerol and urea and is generally located to the basolateral 
membrane of epithelial cells (Ishibashi et al., 1994; Sasaki et al., 1998). AQP 4 is a mercury insensitive water channel also generally localized to the basolateral membranes of a variety of cells (Jung et al., 1994; Hasegawa et al., 1994; Terris et al., 1995). AQP 5 plays a role in the secretion of saliva, tears and pulmonary fluid (Raina et al., 1995; Ma et al., 1999) and is localized in apical membranes. Null murine mutants for AQP 5 display a marked reduction in saliva production (Ma et al., 1999). AQP 6 may be exclusively expressed in kidney and displays a low water conducting ability (Yasui et al., 1999). AQP 7 permits the passage of both water and glycerol and is expressed in a transient fashion in late spermatids and maturing sperm and weakly in kidney and heart (Ishibashi et al., 1997). AQP 8 is also localized in the testes as well as placenta, colon, liver, and heart (Ma et al., 1997). AQP 9 is the most recently cloned water channel and is most similar to AQP 3 and 7 in that it also permits glycerol transport. It is expressed in leukocytes and liver and weakly expressed in the heart, kidney and small intestine (Koyama et al., 1997; Ishabishi et al., 1998).

We have hypothesized that AQPs are likely to be involved in mediating the trans-epithelial water movements that occur in conjunction with blastocyst formation. As an important first step in testing this hypothesis we have examined the presence of AQP mRNAs during murine preimplantation development and discovered that mRNAs encoding seven different AQP family members are present during preimplantation development. Three of these AQPs (AQP 3, 7 and 8) displayed an obvious increase in signal at the morula and blastocyst stage. Future experiments will investigate the functional roles of these AQPs to blastocyst formation and will attempt to localize the distribution of each expressed AQP during early development as effective antisera for each AQP become available. The pursuit of functional data is hampered by the absence of 
specific AQP inhibitors. The existence of AQP null mutant murine lines and the application of antisense oligodeoxynucleotide approaches will enable us to explore the individual and collective roles that AQPs play during early development. This study therefore reports the presence of a new gene family during the first week of development and highlights the utility of the trophectoderm as an important cell model for the investigation of cell polarity, ion transport and now water transport during epithelial cell morphogenesis during development.

\section{Acknowledgements}

We are grateful to Mr Dave Natale for assistance with murine embryos collections. This work was supported by an NSERC Post Graduate Scholarship to LCB, an NSERC operating grant to AJW and Danish Research Foundation funding to HO. 


\section{REFERENCES}

Agre P (1997): Molecular physiology of water transport: aquaporin nomenclature workshop.mammalian aqaporins. Biol Cell 89:255-257.

Baltz JM, Smith SS, Biggers JD, Lechene C (1997): Intracellular ion concentrations and their maintenenanc by $\mathrm{Na/K}$-ATPase in preimplantation embryos. Zygote 5:1-9.

Barcroft LC, Hay-Schmidt A, Caveney A, Gilfoyle E, Overstrom EW, Hyttel P, Watson AJ (1998): Trophectoderm differentiation in the bovine embryo: characterization of a polarized epithelium. J ReprodFert 114: 327-339

Betts DH, MacPhee DJ, Kidder GM, Watson AJ (1997): Ouabain Sensitivity and expression of $\mathrm{Na} / \mathrm{K}-\mathrm{ATPase}$ alpha- and beta-subunit isoform genes during bovine early development. Mol Reprod Dev 46 114-126

Betts DH, Barcroft LC, Watson AJ. (1998): Na/K-ATPase-mediated $86 \mathrm{RB}+$ uptake and asymmetrical trophectoderm localization of $\alpha 1$ and $\alpha 3 \mathrm{Na} / \mathrm{K}-\mathrm{ATP}$ ase isoforms during bovine preattachment development. Dev Biol 197: 77-92

Biggers JD, Bell JE, Benos DJ (1988): Mammalian Blastocyst: transport functions in a developing epithelium. Am J Physiol 255:C419-C432.

Bolton VN. (1992): Controversies and opinions in embryo culture: two-to four-cell transfer vs blastocyst. J Assist Reprod Genet. 9:506-508.

Borgnia M, Nielson S, Engel A, Agre P (1999): Cellular and molecular biology of the aquaporin water channels. Annu Rev Biochem 68:425-458.

Dainty J. (1965): Osmotic flow. Symp Soc Exp Biol 19:75-85.

Davies JA, Garrod DR. (1997): Molecular aspects of the epithelial phenotype. BioEssays 19:699704.

Deen PMT, van Os CH. (1998): Epithelial aquaporins. Cur Opin Cell Biol 10:435-442.

Dizio SM, Tasca RJ (1977): Sodium-dependent amino acid transport in preimplantation mouse embryos. III Na/K-ATPase linked mechanism in blastocysts. Dev Biol 59:198-205.

Echevarria M, Windhager FE, Tate SS, Frindt G. (1994): Cloning and expression of AQP1 a water channel from the medullary collecting duct of rat kidney. Proc Natl Acad Sci USA 91:10997-11001.

Edwards RG. (1997): Recent scientific and medical advances in assisted human conception. Inter J Dev Biol 41: 255-262. 
Fleming TP, McConnell J, Johnson MH, Stevenson BR. (1989): Development of tight junctions de novo in the mouse early embryo: control of assembly of the tight junction-specific protein, ZO-1. J Cell Biol 108:1407-1418.

Fushimi K, Uchida S, Hara Y, Hirata Y, Marumo F, Sasaki S. (1993): Cloning and expression of apical membrane water channel of rat kidney collecting tubule. Nature 361:549-552.

Gardiner CS, Williams JS, Menino AR (1990) Sodium/potassium adenosine triphosphatase ?] and ? ?? ?-subunit and ?-subunit mRNA levels during mouse embryo development in vitro. Biol Reprod 43:788-794.

Harris HW Jr, Zeidal ML. (1993): Water channels. Curr Opin Nephrol Hypertens 2:699-707.

Harvey MB, Arcellana-Panlilio MY, Zhang X, Schultz GA, Watson AJ (1995): Expression of genes encoding antioxidant enzymes in preimplantation mouse and cow embryos and primary bovine oviduct cultures employed for embryos coculture. Biol Reprod 53 530-538

Hasegawa H, Ma T, Skach W, Matthay MA, Verkman AS. (1994): Molecular cloning of a mercuryinsensitive water channel expressed in selected water transporting tissues. J Biol Chem 269:5497-5500.

Heymann JB, Agre P, Engel A. (1998): Progress on the structure and function of aquaporin 1. J Struct Biol 121:191-206

Horisberger JD (1995): Inhibitors of the sodium pump:toxins, then drugs and now hormones. Arch Toxicol Suppl 17:116-124.

Ishibashi K, Sasaki S, Fushimi K, Uchida S, Kuwahara M, Saito H, Furukawa T, Nakajima K, Yamaguchi Y, Gojobori T, Marumo F. (1994): Molecular cloning and expression of a member of the aqaporin family with permeability to glycerol and urea in addition to water expressed at the basolateral membrane of kidney collecting duct cells. Proc Natl Acad Sci USA 91:6269-6273.

Ishibashi K, Kuwahara M, Kageyama Y, Tohsaka A, Marumo F, Sasaki S. (1997): Cloning and functional expression of a second new aquaporin abundantly expressed in testis. Biochem Biophys Res Comm 237:714-718.

Ishibashi K, Kuwahara M, Gu Y, Tanaka Y, Marumo F, Sasaki S. (1998): Cloning and functional expression of a new aquaporin (AQP9) abundantly expressed in the peripheral leukocytes permeable to water and urea but not to glycerol. Biochem Biophys Res Comm 244:268-274.

Jung JS, Bhat RV, Preston GM, Guggino WB, Baraban JM, Agre P. (1994): Molecular characterization of an aquaporin cDNA from brain:candidate osmoreceptor and regulator of water balance. Proc Natl Acad Sci USA 91:13052-13056. 
Katsura T, Ausiello DA, Brown D. (1996): Direct demonstration of aquaporin-2 water channel recycling in stably transfected LLC-PK1 epithelial cells. Am J Physiol 270:F548-F553.

Koyama Y, Yamamoto T, Kondo D, Funaki H, Yaoita E, Kawasaki K, Sato N, Hatakeyama K, Kihara I. (1997):Molecular cloning of a new aquaporin from rat pancreas. J Biol Chem 272:30329-30333.

Lee MD, King LS, Agre P. (1997): The aquaporin family of water channel proteins in clinical medicine. Medicine 76:141-156.

Ma T, Yang B, Verkman AS. (1997): Cloning of a novel water and urea-permeable aquaporin from mouse expressed strongly in colon, placenta, liver and heart. Biochem Biophys Res Comm 240:324-328.

Ma T, Song Y, Gillespie A, Carlson EJ, Epstein CJ, Verkman AS. (1999): Defective secretion of saliva in transgenic mice lacking aquaporin-5 water channels. J Biol Chem 274:20071-20074.

MacPhee DJ, Jones DH, Barr KJ, Betts DH, Watson AJ, Kidder GM (2000): Differential involvement of $\mathrm{Na} / \mathrm{K}-\mathrm{ATPase}$ isozymes in preimplantation development of the mouse. Dev Biol In press.

Mclaren A (1982): The embryo. In Austin CR, Short RV editors. Reproduction in Mammals: Embryonic and Fetal Development. Cambridge: Cambridge University Press.pp 1-26.

Mulders SM, van Lieburg AF, Monnens LAH, Knoers NVAM, Deen PMT, van OS CH. (1996): Physiology and pathophysiology of aquaporins. Eur J Clin Invest 26:1041-1050.

Murer H, Biber J. (1998): Membrane permeability epithelial transport proteins:physiology and pathophysiology. Cur Opin Cell Biol 10:429-434.

Natale DR, Kidder GM, Westhusin ME, Watson AJ (2000) Assessment by differential display-RTPCR of mRNA transcript transitions and ?]?- amanitin sensitivity during bovine preattachment development. Mol Reprod Dev 55:152-163.

Paganelli CV, Solomon AK. (1957):The rate of exchange of tritiated water across the human red blood cell membrane. J Gen Physiol 41:259-277.

Raina S, Preston GM, Guggino WB, Aqre P. (1995): Molecular cloning and characterization of an aquaporin cDNA from salivary, lacrimal and respiratory tissues . J Biol Chem 270:1908-1912.

Sasaki S, Ishibashi K, Marumo F. (1998): Aquaporin-2 and -3: representatives of two subgroups of the aquaporin family colocalized in the kidney collecting duct. Annu Rev Physiol 60:199-220.

Shiels A, Griffin CS. (1993): Aberrant expression of the gene for lens major intrinsic protein in the CAT mouse. Curr Eye Res 12:913-921. 
Simmons C. (1992): The development of cellular polarity in transport epithelia. Sem Perinatol 16:78-89.

Spindle A (1980): An improved culture medium for mouse blastocysts. In Vitro. 16:669-674. Spring KR. (1998). Routes and mechanism of fluid transport by epithelia. Ann Rev Physiol. 60:105119.

Terris J, Ecelbarger CA, Marples D, Knepper MA, Nielsen S. (1995): Distribution of aquaporin-4 water channel expression within rat kidney. Am J Physiol 38:F775-F785.

van Lieburg AF, Verdijk MA, Knoers VV, van Essen AJ, Proesmans W, Malimann R, Monnens LA, van Oost BA, van Os CH, Deen PM. (1994): Patients with autosomal nephrogenic diabetes insipidus homozygous for mutations in the aquaporin 2 water channel gene. Am J Hum Genet 55:648-652.

Verkman AS (1999): Lessons on renal physiology from transgenic mice lacking aquaporin water channels. J Am Soc Nephrol 10: 1126-1135.

Vestweber D, Gossler A, Boller K, Kelmer R (1987): Expression and distribution of cell adhesion molecule uvomorulin in mouse preimplantation embryos. Dev Biol 124:451-456

Vorbrodt A, Konwinski M, Solter D, Koprowski H (1977): Ultrastructural cytochemistry of membrane-bound phsophatases in preimplantation mouse embryos. Dev Biol 124:451-456.

Watson AJ, Pape C, Emanuel JR, Levenson R, Kidder GM (1990a): Expression of Na/K-ATPase ?]land subunit genes during preimplantation development of the mouse. Dev Genet 11:41-48.

Watson AJ, Damsky CH, Kidder GM. (1990b): Differentiation of an epithelium: factors affecting the polarized distribution of Na/K-ATPase in mouse trophectoderm. Dev Biol 141:104-114.

Watson AJ. (1992): The cell biology of blastocyst development. Mol Reprod Dev 33:492-504

Watson AJ, Hogan A, Hahnel A, Wiemer KE, Schultz GA (1992) Expression of growth factor ligand and receptor genes in the preimplantation bovine embryo. Mol Reprod Dev 31: 87-95

Watson AJ, Watson PH, Arcellana-Panlilio M, Warnes D, Walker SK, Schultz GA, Armstrong DT, Seamark RF (1994): A growth factor phenotype map for ovine preimplantation development. Biol Reprod 50: 725-733

Wiley L (1987): Development of the blastocyst: role of cell polarity in cavitation and cell differentiation. In Bavister B editor. The Mammalian Preimplantation Embryo: Regulation of Growth and Differentiation In vitro. Plenum Publishing Company, New York, NY. pp 65-93.

Wilson PD. (1997): Epithelial cell polarity and disease. Am J Physiol 272(41):F434-F442. 
Winger QA, de los Rios P, Han VKM, Armstrong DT, Hill DJ, Watson AJ. (1997): Bovine oviductal and embryonic insulin-like growth factor binding proteins: possible regulators of "embryotrophic" insulin-like growth factor circuits. Biol Reprod 56:1415-1423.

Wintour EM. (1997): Water channels and urea transporters. Clin Exper Pharm Physiol 24:1-9. Yang B, Folkesson HG, Yang J, Matthay MA, Ma T, Verkman AS. (1999): Reduced osmotic water permeability of the peritoneal barrier in aquaporin -1 knockout mice. Am J Physiol 276(45):C76C81.

Yang B, Verkman AS. (1997): Water and glycerol permeabilities of aquaporins 1-5 and MIP determined quantitatively by expression of epitope-tagged constructs in Xenopus oocytes. J Biol Chem 272:16140-16148.

Yasui M, Hazama A, Kwon TH, Nielsen S, Guggino WB \& Agre P (1999): Rapid gating and anion permeability of an intracellular aquaporin. Nature 402 184-187.

Zeidel ML. (1998): Recent advances in water transport. Sem Nephro 18:167-177.

Zeuthen T. (1995): Molecular mechanisms for passive and active transport of water. Inter Rev Cyto 160:99-161. 
Table 1 AQP Primer Sequences

\begin{tabular}{|c|c|c|c|}
\hline PCR Product & primer sequences & size (bp) & $\begin{array}{l}\text { GenBank Accession } \\
\text { Number }\end{array}$ \\
\hline AQP 1 & $\begin{array}{l}\text { 5'-primer: } \\
\text { GGCTATGTGCAGTGTCATGTC } \\
\text { 3'-primer: } \\
\text { CTGTGATATGCCAGTGGTCAG }\end{array}$ & 462 & L02914.1 \\
\hline AQP 2 & $\begin{array}{l}\text { 5'-primer: } \\
\text { TGGATTCATGGAGCAGCCGGT } \\
\text { 3'-primer: } \\
\text { TCCTTCCTTCGAGCTGCCTTC }\end{array}$ & 312 & AF020519.1 \\
\hline AQP 3 & $\begin{array}{l}\text { 5'-primer: } \\
\text { CCTCTGGACACTTGGATATGG } \\
\text { 3'-primer: } \\
\text { CAGCTTCACATTCTCTGCCTC }\end{array}$ & 398 & D17695 \\
\hline AQP 4 & $\begin{array}{l}\text { 5'-primer: } \\
\text { AGCATCGCCAAGTCTGTCTTC } \\
\text { 3'-primer: } \\
\text { TCCTCCACCTCCATGTAGCTC }\end{array}$ & 515 & U14007.1 \\
\hline AQP 5 & $\begin{array}{l}\text { 5'-primer: } \\
\text { ATCTACTTCACCGGCTGTTCC } \\
\text { 3'-primer: } \\
\text { GTCAGCTCGATGGTCTTCTTC }\end{array}$ & 260 & U16245.1 \\
\hline AQP 6 & $\begin{array}{l}\text { 5'-primer: } \\
\text { AGTCAACGTGGTCCACAACAG } \\
\text { 3'-primer: } \\
\text { GTTGTAGATCAGCGAAGCCAG }\end{array}$ & 304 & AF083879.1 \\
\hline AQP 7 & $\begin{array}{l}\text { 5'-primer: } \\
\text { AACTGTGCACTAGGCCGAATG } \\
\text { 3'-primer: } \\
\text { GTGATGGCGAAGATACACAGC }\end{array}$ & 269 & AB000507.1 \\
\hline AQP 8 & $\begin{array}{l}\text { 5'-primer: } \\
\text { GAACATCAGCGGTGGACACTT } \\
\text { 3'-primer: } \\
\text { CGATGAGGAGCCTAATGAGCA }\end{array}$ & 497 & AF018952.1 \\
\hline AQP 9 & 5'-primer: & 278 & AB013112.1 \\
\hline
\end{tabular}




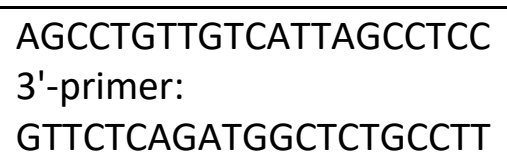

Figure 1. Detection of AQP mRNA transcripts during murine preimplantation development. Each lane represents the specific AQP RT-PCR products derived from total RNA representing the equivalent of 2 embryos. Transcripts encoding AQPs $1,2,3,4,5,6,7,8$, and 9 were investigated with expected amplicon sizes of 462, bp, 312 bp, 398 bp, 515 bp, 260 bp, 304 bp, 269 bp, 497 bp and 278 bp respectively. The lanes are 100 bp DNA ladder; + positive tissue control (murine kidney for AQPs 1,2,3,4,and 6; murine lung for AQP 5; and murine liver for AQPs 7,8, and 9); 00, matured oocytes; 2, 2-cell stage embryos; 4, 4-cell stage embryos; 8, 8-cell stage embryos; M, morula stage embryos; Bl, blastocyst stage embryos. Transcripts encoding AQPs 1,3,5,6,7, and 9 were detected from the oocyte to blastocyst stage. Transcripts encoding AQPs 2 and 4 were not detected in preimplantation embryos stages while AQP 8 transcripts were only detected in morula and blastocyst stages. All RT-PCR experiments were repeated for each AQP primer set on RNA samples isolated from a minimum of three separate embryos series. 
Figure 2: Sequence identity of Murine embryo AQP RT-PCR products: Nucleotide sequences of AQP 1,3,5,6,7,8, and 9 RT-PCR products were compared to the corresponding murine and rat sequences in Genbank. Areas of non-conserved bases are highlighted. 
FIGURE 2: AQP PCR product sequences

Mouse AQP 1 PCR product. $\quad 99 \%$ identical to the mouse AQP1 GenBank sequence

ggctatgtgcagtgtcatgtctgaggagagaagcagctagctatgcaacagaccctggacagatgcccatgctgggcacacaagggttt ggatgcccttagttcatcatgagcaaggaggtcactctggccctggcttgtgagctcctggctggatgagtgtgaccggagcctggacaat ctgcagaggctcactctgtgcctccaggcacagtcttctctctgcattggcccaatgctacagcttgtgttgcagcccaaggacagctcag agtgcagtcagctcaggggttgcatttagctctaggtcattccattggatcccatcaatccagagtggctctaccactgtgccttaaccac attgtgaaccgagagccacattcttcaggtgcttagaagcagcagaagagtcagaaggccactgaccactggcatatcacag

Mouse AQP 3 PCR product. $\quad 98 \%$ identical to the mouse AQP 3 Genbank sequence cctctggacacttggatatggtcaatggcttctttgatcagttcataggcacagccgcccttattgtgtgtgtactggccatcgttgaccctt ataacaacctgtgcccegtggcctggaggctttcactgtgggcctggtggtcctggtcattggaacctccatgggcttcaattctggctat gccgtcaaccctgcccgtgactttggacctcgcctcttcaccgccctggctggctggggctcagaagtcttcacgactggccggcactggt ggtgggtacccattgtctcccactcctgggttccatcgttggtgtcttcgtgtaccagctcatgattggttgccacctggagcagccccac cctccaccgaggcagagaatgtgaagctg

Mouse AQP 5 PCR product. $100 \%$ identical to the mouse AQP 5 GenBank sequence atctacttcaccggctgttccatgaacccagcccgatctttcggccctgcggtggtcatgaatcggttcagcccctctcactgggtcttctgg gtaggaccgatcgtgggggccgtcctggctgcaatcctctacttctacttgcttttcccctcctcgctgagcctccacgaccgtgtggctgtg gtcaaaggcacatatgagccagaggaggactgggaagatcatagagaggagcggaagaagaccatcgagctgac

Mouse AQP 6 PCR product. $95 \%$ identical to the rat AQP 6 GenBank sequence agtcaacgtggtccacaacagcacatcaactggccaggcggtggccgtggagctggttctgacgctgcagctggtgctctgtgtctttgct tccatggatggccggcagaccttggcgtccccagctgccatgattggaacctctgtggcactgggccacctcattgggatctacttcactg gctgttccatgaacccagccegctccttcggccctgccgtcattgttgggaagttcgcagtccattggatcttctgggtaggaccgctcaca ggggctgtcctggcttcgctgatctacaac

Mouse AQP 7 PCR product. 99\% identical to the mouse AQP 7 GenBank sequence tgtgcactaggccgaatgacctggaagaagttccctgtatatgtgctgggtcagttcctgggctccttctcagctgcagctaccacctactt aattttctatggtgccattaaccactttgcaggcggagacctgttggtgacaggttccaaggccgctgcaaacattttgccacctatcttcc tgaatacatgacactgtggcggggcttcctggatgaggcattcgtgactgggatgctgcagctgtgtatcttcgccatcac

Mouse AQP 8 PCR product. $\quad 100 \%$ identical to the mouse AQP 8 GenBank sequence gaacatcagcggtggacacttcaaccctgctgtgtcgctggcagtcacagtgatcggaggcctcaagaccatgctgctaattccctattgg atctcccagctatttggagggctgattggggctgccttggctaaagtggtgagtccagaggaaagattctggaatgcatctggggcagcc tttgccatcgtccaggagcaggagcaggtggcagaagccctggggatagagatcattctgacaatgctgttggtattggctgtgtgtatgg gtgctgtcaatgagaagacaatgggccctttagccccattctccattggcttctctgtcattgtggacatcctggcaggtggtagcatctctg gagcctgcatgaacctgctcgtgcctttggacctgctgtgatggctggctactgggacttccattggatctactggctgggcccctcctg gctggcctctttgtaggactgctcattaggctcctcatcg

Mouse AQP 9 PCR product. $\quad 92 \%$ identical to the rat AQP 9 GenBank sequence gggtcggggttcgagtgatgcatttggataaaaagaacatagatgagacctcccaggacagctccaatcatagggcccacgacaggtat 
ccaccagaagttatttccaaatgtgaagacctnaaatccccatcctgccagagcagtgaanagcctggggctgaggtctcgagcagggt tcatggcacaaccagagttgagtccgagagaacaggaaatgacaatgattaggaggctaatgacaacaggct 